\title{
ULTRAMORPHOLOGICAL ANALYSIS OF THE VENOM GLANDS AND THEIR HISTOCHEMICAL RELATIONSHIP WITH THE CONVOLUTED GLANDS IN THE PRIMITIVE SOCIAL PAPER WASP Polistes versicolor (HYMENOPTERA: VESPIDAE)
}

\author{
BRITTO F. B. (1); CAETANO F. H. (1)
}

(1) Department of Biology, Rio Claro Institute of Biosciences, São Paulo State University (UNESP), Rio Claro, São Paulo, Brazil.

\begin{abstract}
The venom glands are part of the most important defense weapon in Aculeata: the venom apparatus. The arrangement of these glands can vary among species, but in general they are composed of long secretory tubules connected to a muscular sac-like reservoir. Although the occurrence of these variations has been documented, many studies neglected the existence of a well-developed secretory portion in the lumen of the reservoir named convoluted gland. This study is an ultramorphological analysis of the venom glands and their histochemical relationship with the convoluted glands in the primitive social wasp Polistes versicolor. In this wasp, the venom glands are constituted by two tubular portions that penetrate individually in the venom reservoir, inside of which we can find the convoluted glands. Besides morphological differences in their cells, histochemical analysis of the venom and convoluted glands clearly show differences between them. While the venom glands indicate positive reaction only for proteins, the convoluted glands present positive reaction for proteins, neutral glycoconjugates, and lipids. The secretion of the convoluted gland cells may modify the compounds passing through the embedded tubular region.
\end{abstract}

KEY WORDS: wasps, venom glands, convoluted glands, ultramorphology, histochemistry.

CORRESPONDENCE TO: F. B. BRITTO, Universidade Estadual Paulista (UNESP), Instituto de Biociências, Departamento de Biologia, Av. 24A, 1515, 13506-900, Rio Claro, SP, Brasil. Email: fbbritto@yahoo.com 
F. B. Britto et al. ULTRAMORPHOLOGICAL ANALYSIS OF THE VENOM GLANDS AND THEIR HISTOCHEMICAL RELATIONSHIP WITH THE CONVOLUTED GLANDS IN THE PRIMITIVE SOCIAL PAPER WASP Polistes versicolor (HYMENOPTERA: VESPIDAE). J. Venom. Anim. Toxins incl. Trop. Dis., 2005, 11, 2, p. 161

\section{INTRODUCTION}

The venom apparatus of the Hymenoptera is directly derived from the ovipositor and functions as an effective defense weapon for the colony in Aculeata (9). The anatomy of this structure reveals the presence of two important associated exocrine glands, named venom gland and Dufour gland (3).

Bordas (3) and Carlet (7) believe that the venom gland, as well as the Dufour gland, plays a role in the production of venom. However, the venom gland discharges its secretion at the tip of the sting, unlike the Dufour gland that does it near the sting base and therefore is not directly related to this function (15).

The venom glands have ectodermic origin and their organization has the same patterns in all the studied Hymenoptera. They are constituted by type III cells, according to the Noirot \& Quennedey (19) classification, which are described as secretory cells with canaliculi responsible for collecting and conducting the secretion until its destination.

The morphology of the venom glands can vary according to the species, but in general, they are composed of long secretory tubules, attached to a sac-like reservoir. Previous studies on the morphology of venom glands showed that they are constituted by two lengthened cylindrical tubules in Apinae, Adreninae, and Bombinae that become fused before connecting to the reservoir. In Vespinae, Polistinae, and Eumeninae they are entirely separated. In the subfamilies Sphecinae, Phylantinae, and Cabroninae these tubules present some short ramifications, constituted by thick branches $(3,14,18,25$, 26).

Histological studies on some Hymenopteran species described the tubular portion of the venom glands as essentially composed by cylindrical cells and its epithelium internally coated with cuticle. This epithelium delimitates a narrow lumen $(5,14,22)$.

In ants and social wasps, most studies on venom glands focused on the tubular portion, which is clearly visible when dissecting this gland. This portion is considered a synonym for what is called venom gland. Another secretory epithelium, however, was found inside the reservoir, being denominated convoluted gland $(6,23,24)$. In social bees, the convoluted glands are not present, but there are some glandular cells in the venom reservoir wall. These cells could have a similar function to the convoluted glands (8). 
F. B. Britto et al. ULTRAMORPHOLOGICAL ANALYSIS OF THE VENOM GLANDS AND THEIR HISTOCHEMICAL RELATIONSHIP WITH THE CONVOLUTED GLANDS IN THE PRIMITIVE SOCIAL PAPER WASP Polistes versicolor (HYMENOPTERA: VESPIDAE). J. Venom. Anim. Toxins incl. Trop. Dis., 2005, 11, 2, p. 162

There are some ultrastructural differences between the cells of the tubular portion and the cells of the convoluted glands in wasps and ants $(23,24)$. The same was observed in Apis mellifera regarding the cells of the tubular portion and the secretory cells found inside the reservoir wall (8). Also, histochemical differences were found between the tubular portion and the convoluted glands in ants (20).

The main ultrastructural characteristics found in the venom gland apparatus revealed that it is related to the production of a protein secretion (5), although components like polysaccharides and lipids have been identified in other studies (1).

Therefore, this study examines the venom glands external morphology and their histochemical relationship with the convoluted glands in the primitive social paper wasp Polistes versicolor, describing the main components produced by these glands.

\section{MATERIAL AND METHODS}

Ultramorphological and histochemical studies were carried out in different specimens of $P$. versicolor. These specimens were cold anesthetized, dissected and their venom apparatuses were fixed in $4 \%$ paraformaldeyde for 2 hours.

\section{Ultramorphology}

For the external structure observations, after fixation, the venom apparatuses of five wasps were dehydrated in a graded acetone series $(50 \%, 60 \%, 70 \%, 80 \%, 90 \%$, and $100 \%$ ) for 10 minutes in each concentration. The material was dried in a Balzers CPD 030 Critical Point and fixed to aluminum stubs with adhesive tape. After this procedure the venom apparatuses were sputtered with carbon and gold in a Balzers SCD 050 critical point and examined by Jeol-JSM-P15 Scanning Electron Microscopy.

\section{Histochemistry}

After fixation, the venom apparatuses of 15 wasps were transferred to a sodium phosphate buffer $(\mathrm{pH} \mathrm{7.4)}$ for five hours, and later dehydrated in a standard ethanol series $(70 \%, 80 \%, 90 \%$, and $95 \%)$ for 30 minutes in each concentration. Then, the material was embedded in resin (Leica) for 24 hours. After this procedure, the resin was 
F. B. Britto et al. ULTRAMORPHOLOGICAL ANALYSIS OF THE VENOM GLANDS AND THEIR HISTOCHEMICAL RELATIONSHIP WITH THE CONVOLUTED GLANDS IN THE PRIMITIVE SOCIAL PAPER WASP Polistes versicolor (HYMENOPTERA: VESPIDAE). J. Venom. Anim. Toxins incl. Trop. Dis., 2005, 11, 2, p. 163

polymerized at $37^{\circ} \mathrm{C}$, sectioned to $5 \mu \mathrm{m}$ thickness with the aid of a microtome, and the sections were arrayed on glass slides.

Part of the material was assigned to the Xylidine Ponceau technique (17), which stains total proteins. In this technique the material was first hydrated with distilled water and stained with Xylidine Ponceau for 15 minutes. After this procedure, the slides were transferred to a solution of $2 \%$ acetic acid for 30 minutes and washed with distilled water.

Another part of the material was assigned to the conjugated PAS-Alcian Blue test, which simultaneously detects neutral glycoconjugates with 1,2 glycol and acid glycoconjugates, respectively (10). The glass slides containing the glands were hydrated with distilled water and transferred to a solution of Alcian Blue ( $\mathrm{pH} 2.5)$ for 30 minutes, and washed with distilled water. Then, they were immersed in $1 \%$ periodic acid for 5 minutes, and washed once more. The glass slides were stained with Shiff reagent for 15 minutes, and washed in tap water for 15 minutes. Part of this material was counterstained with hematoxylin to visualize the nuclei morphology.

The last part of the glass slides was assigned to the Sudan Black technique (10) for the detection of lipids. The material was quickly immersed in a solution of $75 \%$ ethanol and stained with Sudan Black for 45 minutes. After this procedure, the material was washed in $75 \%$ ethanol.

\section{RESULTS}

In $P$. versicolor, the venom glands are constituted by two free tubular portions that are individually connected to the venom reservoir (Figure 1a). These tubules are cylindrical and present some slight protuberances on their surface, produced by imprinting of their epithelial cells (Figure 1b). These cells form an epithelium that delimits a narrow lumen, which are coated with cuticle (Figure 1c). There is not an external musculature surrounding them.

At the insertion point of the venom gland into the reservoir, the tubular portion becomes narrower. In this region, it is possible to see the tubular portion penetrating between two muscular fibers of the reservoir (Figure 1d). 
F. B. Britto et al. ULTRAMORPHOLOGICAL ANALYSIS OF THE VENOM GLANDS AND THEIR HISTOCHEMICAL RELATIONSHIP WITH THE CONVOLUTED GLANDS IN THE PRIMITIVE SOCIAL PAPER WASP Polistes versicolor (HYMENOPTERA: VESPIDAE). J. Venom. Anim. Toxins incl. Trop. Dis., 2005, 11, 2, p. 164

The reservoir is basically a muscular structure, constituted by muscular fibers arranged obliquely and transversely in four different lobules (Figure 1d). Some tracheas are present on the reservoir tissue (Figure 1d). At its proximal region, there is an excretory duct that leads the stored venom until it reaches the sting (Figures 1a and 1d).

Histologically, the external tubular portion presents well-defined cells with spherical nuclei (Figure 2a). These cells have a prominent extra-cellular matrix in their basal region that covers the entire tubular portion. The intercellular spaces between the secretory cells are pronounced (Figure 2a). At its proximal region, the gland crosses the reservoir wall (Figure $2 \mathrm{~b}$ ) and the epithelial tissue, initially consisted of typical cells, becomes irregular with not well-defined cells, characterizing the beginning of the convoluted gland (Figures 2c, 2d, and 2e). Anatomically, the convoluted gland consists of a glandular epithelium with one side facing the reservoir lumen and another side facing a space that is continuous with the hemolymph (Figures. $2 c$ and $2 d$ ).

The convoluted glands present an irregular epithelium with columnar cells in the most of its tissue (Figure 2e). These cells possess basal and oval-shaped nuclei and their apical faces are turned to the reservoir lumen (Figure $2 \mathrm{~d}$ and $2 \mathrm{e}$ ). In this region, these cells store secretions characterizing them as polarized cells (Figure $2 \mathrm{e}$ ). Other kinds of cells have flattened cytoplasm and well-developed irregular nuclei, due to the surrounding cell pressure (Figure 2e). These cells are located near the lumen reservoir, in contact with the cuticle layer that covers the convoluted glands (Figure 2e). This cuticle layer is continuous with the cuticle of the external tubular portion and with the cuticle of the venom reservoir (Figure $2 \mathrm{e}$ ).

The reservoir presents a thick muscular wall, which is internally coated with a thick layer of cuticle (Figures $2 \mathrm{~d}, 3 \mathrm{~b}, 3 \mathrm{c}$, and $3 \mathrm{~d}$ ). As in the ultramorphologycal analysis, it is possible to observe the different muscular fiber orientation in the muscular wall (Figure 2b).

Besides morphological differences among the cells, the histochemical analysis of the venom glands and convoluted glands showed clear differences between them. While the venom glands only presented positive reaction for proteins, the convoluted glands presented positive reaction to all the techniques used. 
F. B. Britto et al. ULTRAMORPHOLOGICAL ANALYSIS OF THE VENOM GLANDS AND THEIR HISTOCHEMICAL RELATIONSHIP WITH THE CONVOLUTED GLANDS IN THE PRIMITIVE SOCIAL PAPER WASP Polistes versicolor (HYMENOPTERA: VESPIDAE). J. Venom. Anim. Toxins incl. Trop. Dis., 2005, 11, 2, p. 165

The protein secretion, found in the venom glands cytoplasm, had vesicular form and the vesicles were homogeneously distributed (Figure 3a). These glands did not present positive reaction for lipids and glycoconjugates.

The presence of proteins was also observed in the convoluted glands presenting positive reaction on their whole area (Figure $3 \mathrm{~b}$ ). These glands exhibited homogeneous and strong staining, making it difficult to distinguish the structures of their cells.

Besides the presence of proteins, the histochemical analysis of the convoluted glands indicated the presence of neutral glycoconjugates, however, the glycoconjugates were mainly detected in the apical portion of the cells facing the reservoir lumen (Figure $2 \mathrm{~d}$, $2 \mathrm{e}$, and $3 \mathrm{c}$ ). Other glandular areas presented only a mild reaction to this technique (Figure 3c). Acid glyconconjugates were not observed.

In the technique for detection of lipids, the convoluted glands were homogeneously stained, except for the apical areas, which showed positive reaction to the technique for neutral glycoconjugates (Figure $3 \mathrm{~d}$ and $3 e$ ).

The secretion present inside the reservoir lumen (the venom) exhibited a strong positive reaction for proteins, but a mild reaction for glycoconjugates and a weak reaction for lipids (Figure 3b, 3c, and 3d).

A significant amount of lipids was found in the internal region of the convoluted glands continuous with the hemolymph (Figure $3 \mathrm{~d}$ ). This material was present in the form of relatively large vesicles. 
F. B. Britto et al. ULTRAMORPHOLOGICAL ANALYSIS OF THE VENOM GLANDS AND THEIR HISTOCHEMICAL RELATIONSHIP WITH THE CONVOLUTED GLANDS IN THE PRIMITIVE SOCIAL PAPER WASP Polistes versicolor (HYMENOPTERA: VESPIDAE). J. Venom. Anim. Toxins incl. Trop. Dis., 2005, 11, 2, p. 166
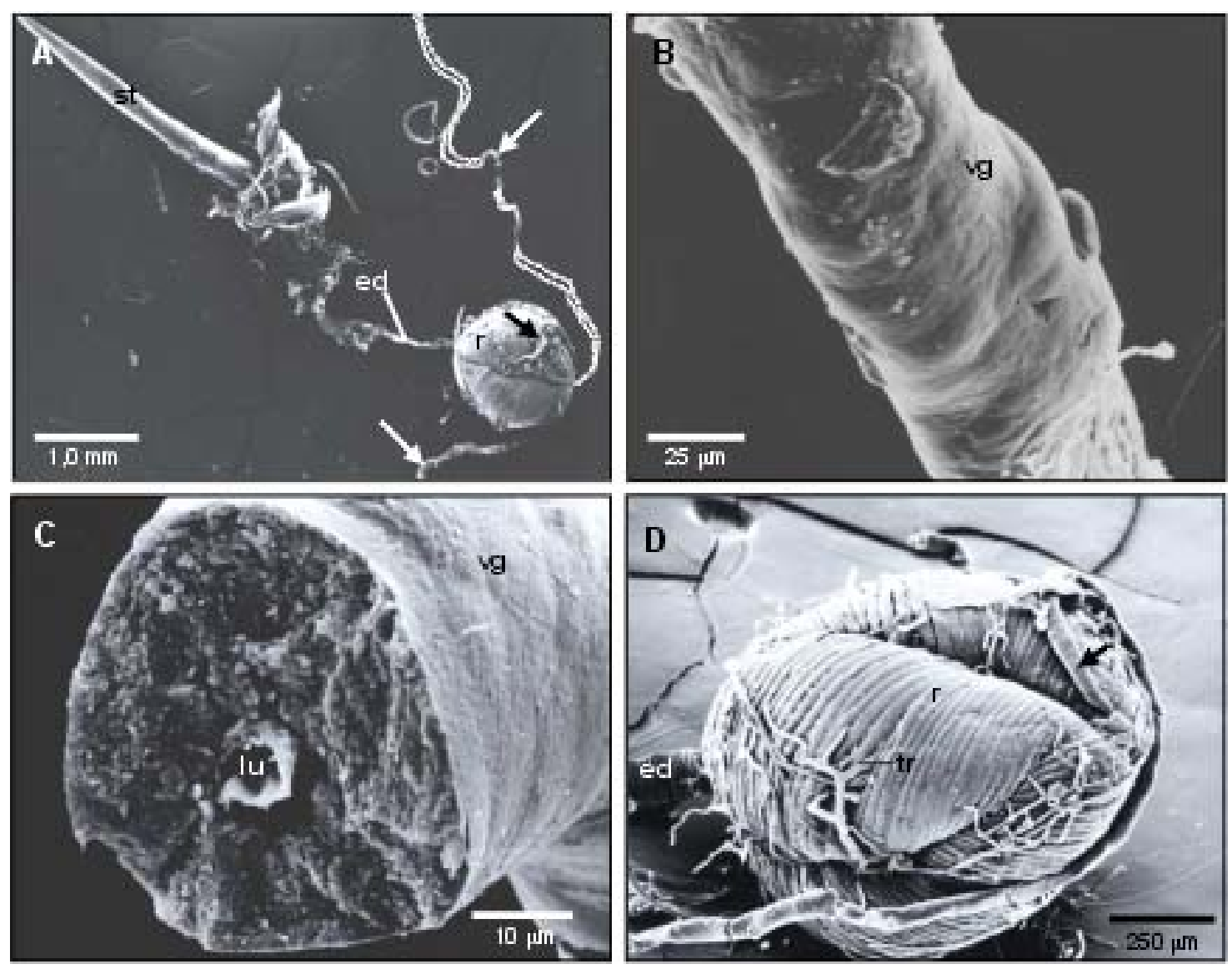

Figure 1 - (A) General view of the venom glands (arrows), reservoir, excretory duct, and sting; (B) Detail of the venom gland; (C) Venom gland penetrating its reservoir (arrow); (D) Broken region of the venom gland showing its lumen. ed - excretory duct; lu - lumen; r - reservoir; st - sting; tr - trachea; vg - venom gland. 
F. B. Britto et al. ULTRAMORPHOLOGICAL ANALYSIS OF THE VENOM GLANDS AND THEIR HISTOCHEMICAL RELATIONSHIP WITH THE CONVOLUTED GLANDS IN THE PRIMITIVE SOCIAL PAPER WASP Polistes versicolor (HYMENOPTERA: VESPIDAE). J. Venom. Anim. Toxins incl. Trop. Dis., 2005, 11, 2, p. 167

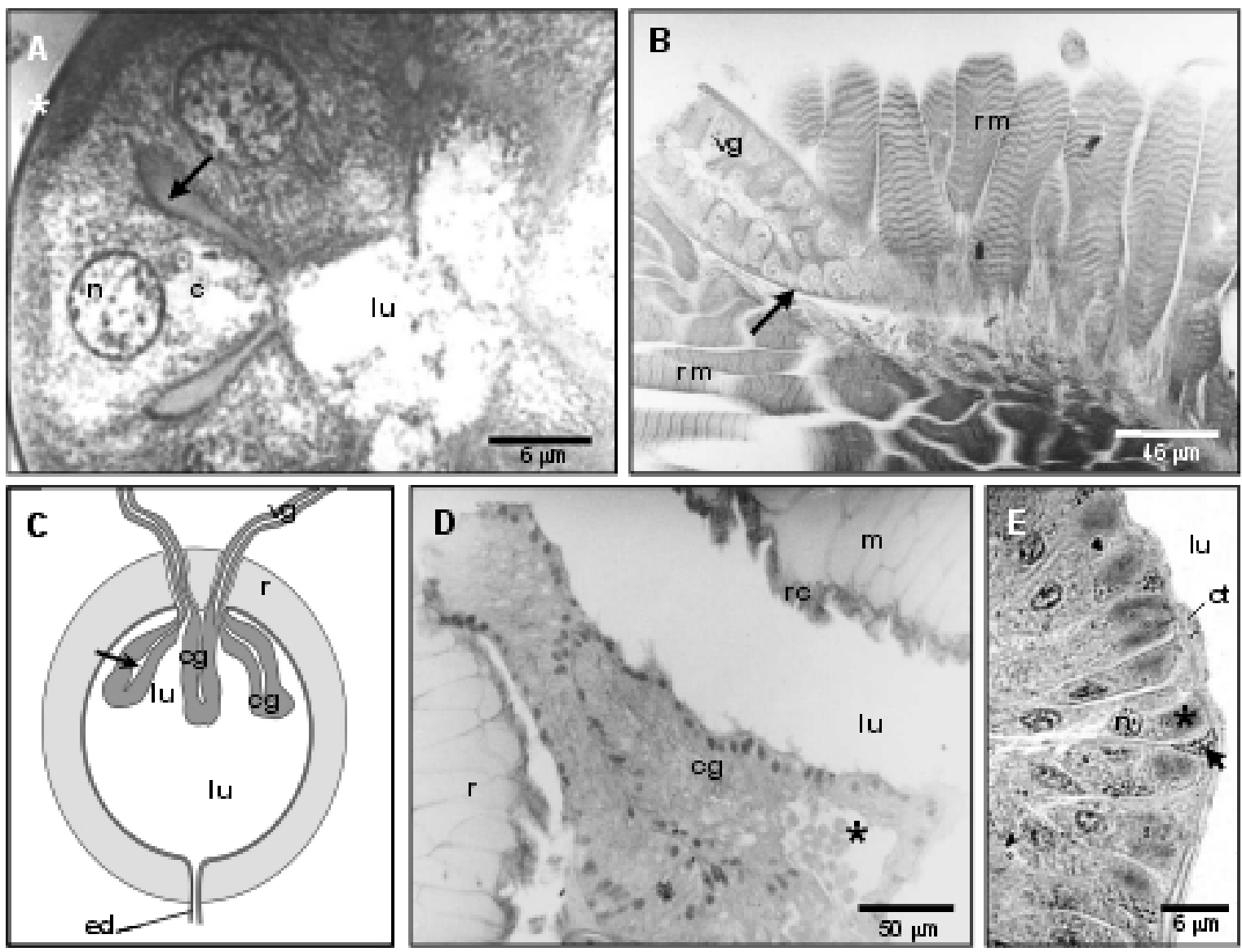

Figure 2 - (A) Venom gland in transversal section view showing its secretory cells (note the prominent intercellular space indicated by the arrow and the extracellular matrix covering the gland indicated by the asterisk); (B) Venom gland penetrating the reservoir wall; (C) Schematic view of the venom glands, convoluted glands, and the reservoir (the arrow indicates the space inside the convoluted gland that is continuous with the hemolymph); (D) Convoluted gland epithelium (the asterisk shows the same region indicated in the previous figure by the arrow); (E) Detail of the convoluted gland showing two epithelial cell types. The first type (arrow) is small and presents a flattened cytoplasm, while the second type occurs in larger numbers resembling columnar cells (the asterisk indicates the accumulation of secretion in the apical area). c - cytoplasm; cg - convoluted gland; ct - cuticle; ed - excretory duct; lu - lumen; $\mathbf{n}$ - nucleus; $\mathbf{r}$ reservoir; rm - reservoir musculature; st - sting; vg - venom gland. 
F. B. Britto et al. ULTRAMORPHOLOGICAL ANALYSIS OF THE VENOM GLANDS AND THEIR HISTOCHEMICAL RELATIONSHIP WITH THE CONVOLUTED GLANDS IN THE PRIMITIVE SOCIAL PAPER WASP Polistes versicolor (HYMENOPTERA: VESPIDAE). J. Venom. Anim. Toxins incl. Trop. Dis., 2005, 11, 2, p. 168
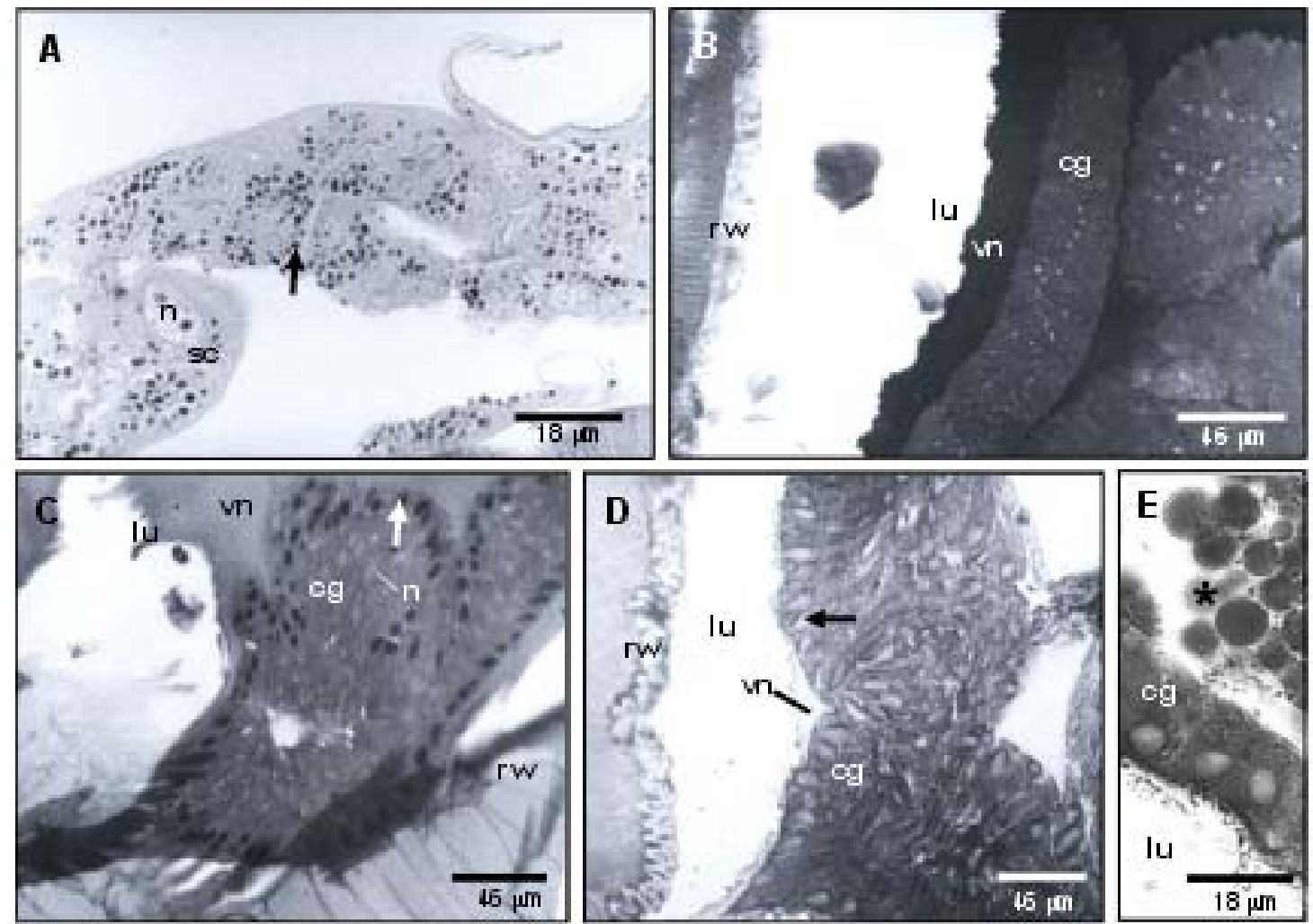

Figure 3 - (A) Venom gland and its secretion showing positive reaction to Xylidine Ponceau (arrow); (B) Convoluted gland with positive reaction to Xylidine Ponceau (note the strong staining of the area containing venom); (C) Convoluted glands with positive reaction to PAS in the apical portions of the cells (arrow), which are in contact with the reservoir lumen; (D) (the arrow is showing the same region that was PAS positive); (E) Detail of the convoluted gland showing its internal region (continuous with the hemolymph) with large amounts of Sudan Black B positive-granules ( $\left.{ }^{*}\right)$. cg - convoluted gland; lu - lumen; $\mathbf{n}$ - nucleus; rw - reservoir wall; sc - secretory cell; vn - venom.

\section{DISCUSSION}

Studies on venom glands have revealed some morphological variations in the hymenopteran groups, but in general, their organization maintains the same pattern. These glands are constituted by one or more secretory tubules that discharge their products into a reservoir. The reservoir may or may not be surrounded by musculature 
F. B. Britto et al. ULTRAMORPHOLOGICAL ANALYSIS OF THE VENOM GLANDS AND THEIR HISTOCHEMICAL RELATIONSHIP WITH THE CONVOLUTED GLANDS IN THE PRIMITIVE SOCIAL PAPER WASP Polistes versicolor (HYMENOPTERA: VESPIDAE). J. Venom. Anim. Toxins incl. Trop. Dis., 2005, 11, 2, p. 169

and, in some cases, secretory cells may be present on its wall. An excretory duct connects the reservoir to the sting (16).

In $P$. versicolor, as also shown by Nascimento \& Cruz-Landim (18), the venom apparatus present a pair or secretory tubules individually connected to a reservoir. These tubules constitute the glandular portion known as venom glands. The reservoir is surrounded by a well-developed musculature and is connected to the sting by an excretory duct. Polistes versicolor, as well as all the social wasps studied, shows an extensive musculature attached to a thick cuticular reservoir wall, whereas solitary wasps have relatively few muscle fibers surrounding the venom reservoir (23). Inside the reservoir, there is an epithelium with well-developed cells, anatomically continuous with the external tubular portion, denominated convoluted gland. Secretory cells were not found in the reservoir wall. Abreu (1) observed the presence of secretory cells in the reservoir wall of $A$. mellifera, however, the venom apparatus of this species did not present convoluted glands. Thus, the secretory cells of the reservoir wall of $A$. mellifera could have a similar function to the convoluted glands.

The external tubular portion (the venom glands) is considered the main responsible for the venom production, as observed in a strain of $A$. mellifera with shortened external tubular portion. These bees produced and stored a significantly reduced amount of venom in their reservoir (2). Silveira \& Caetano $(25,26)$ found a large variation in the length of the external tubular portion in different species of wasps. In $P$. versicolor this region had $13 \mathrm{~mm}$ in length and the reservoir measured $2 \mathrm{~mm}$. Therefore, despite the small diameter in relation to the reservoir, the participation of the external tubular portion in the production of venom is clearly significant. It is mostly constituted by secretory cells that appear as polygonal cells with spherical nuclei.

The convoluted glands of $P$. versicolor presented different kinds of cells in its epithelium, as found in ants and other species of wasps $(23,24)$. These studies pointed out the presence of epithelial cells lining the cuticular portion of the convoluted gland and glandular cells secreting directly into the venom reservoir. In $P$. versicolor, the first type of cell was found underneath the cuticular lining of the convoluted gland. These cells are extremely flattened and only their nuclei are clearly visible. The second cell type consists of a large number of secretory cells that discharge their product directly into the 
F. B. Britto et al. ULTRAMORPHOLOGICAL ANALYSIS OF THE VENOM GLANDS AND THEIR HISTOCHEMICAL RELATIONSHIP WITH THE CONVOLUTED GLANDS IN THE PRIMITIVE SOCIAL PAPER WASP Polistes versicolor (HYMENOPTERA: VESPIDAE). J. Venom. Anim. Toxins incl. Trop. Dis., 2005, 11, 2, p. 170

reservoir, adding it to the already stored venom. They form a continuous layer next to the epithelial cells. The secretory cells appear as columnar cells with completely different apical and basal regions.

The histochemical analysis of the external tubular portion exhibited a positive reaction only for proteins, while the presence of other compounds was not significant. In $P$. versicolor, as in Apis dorsata, the secretion found in the venom gland cells has a granular form (11). Similar structures were found in the venom glands of Vespa orientalis (12). Ultrastructural studies showed a large amount of granular endoplasmic reticulum, Golgi complex, mitochondria, and secretion vesicles in these cells (5), corroborating their specialization in protein synthesis.

Unlike what was observed in the external tubular portion, cells containing proteins as well as glycoconjugates and lipids were also found in the convoluted glands. Glycoconjugate staining occurred mainly in the cells facing the lumen of the venom reservoir. Due to the intense staining pattern only in the apical areas of these cells, it was suggested that these cells are specialized in the production of this material. Moreover, the presence of proteins in the same region indicates that the secretion of these cells is glycoproteic.

Schoeters \& Billen (23) observed that the basal and apical areas of these cells were very distinct in different species of wasps. In the basal areas they found deposits similar to lipidic inclusions. The same authors observed, in ultrastructural studies, that besides the cells that secrete their content directly into the lumen of the reservoir, the convoluted glands also present specific cells, with many lipid deposits, that discharge their contents in the internal space continuous with the hemolymph. In $P$. versicolor large amounts of this material were found in the same area.

Some evidences pointed out that relatively large lipidic masses, observed in the basal portion of glandular cell of bees, suffer fragmentation as they move towards the apical area. These evidences were supported by the presence of large lipidic masses in the basal area, while small granules predominate in the apical zone. Thus, it was suggested that the lipids have an exogenous origin in the hemolymph, and a structural and functional role, as part of the cuticle and of the secretion components, respectively (1). In spite of the low concentration of lipids observed in $P$. versicolor venom at optical level, 
F. B. Britto et al. ULTRAMORPHOLOGICAL ANALYSIS OF THE VENOM GLANDS AND THEIR HISTOCHEMICAL RELATIONSHIP WITH THE CONVOLUTED GLANDS IN THE PRIMITIVE SOCIAL PAPER WASP Polistes versicolor (HYMENOPTERA: VESPIDAE). J. Venom. Anim. Toxins incl. Trop. Dis., 2005, 11, 2, p. 171

it is known that components of lipidic nature are secreted by exocrine glands of insects, mainly by the ones producing pheromones, including sexual attractives, substances of alarm, and trail markers (13).

As mentioned before, this structure is not present in bees. However, inside the reservoir, near the opening of the venom glands, the epithelium is constituted by relatively tall cells with glandular characteristics. In this region, the cells present mainly granular endoplasmic reticulum in the vesicular form and free ribosomes (8). This organization, however, does not suggest a low level of protein synthesis, but may indicate the production of other venom compounds, distinct from the ones produced in the external tubular portion (21).

A blend of more than 50 substances was identified in the venom of $A$. mellifera and many of them have toxic effects on various species of insects and vertebrates (5). Some substances like hyaluronidase, phospholipase A, acid phosphatase, esterase, histamine, dopamine, and noradrenaline were found in pharmacologically significant concentrations (4).

Cruz-Landim \& Kitajima (8) presumed that when the secretion produced in the external tubular portion of $A$. mellifera is discharged, other substances secreted by the venom reservoir epithelium should be added, giving the final form and determining the venom specificity of each species. Ratcliffe \& King (22) also considered that the activation of the venom should occur inside the reservoir, by the secretion of enzymes in this compartment. A similar process could occur in $P$. versicolor as indicated by the results of histochemical analysis of the convoluted glands, clearly showing the production of other components, not present in the external tubular portion.

The question arises: why was such large secretory region of a gland entirely internalized within the reservoir? According to Schoeters and Billen (23), a possible explanation for the origin of the convoluted gland could be related to the origin of the extensive muscular supply associated with the reservoir. Insertion of such amount of muscle fibers on the reservoir would not be possible if most of the reservoir wall had a secretory function.

In a detailed analysis of the convoluted glands of ants, Schoeters and Billen (24) defined a sequence of events that precursor poison molecules would undergo. Initially these 
F. B. Britto et al. ULTRAMORPHOLOGICAL ANALYSIS OF THE VENOM GLANDS AND THEIR HISTOCHEMICAL RELATIONSHIP WITH THE CONVOLUTED GLANDS IN THE PRIMITIVE SOCIAL PAPER WASP Polistes versicolor (HYMENOPTERA: VESPIDAE). J. Venom. Anim. Toxins incl. Trop. Dis., 2005, 11, 2, p. 172

precursors, present in the hemolymph, would cross the cells of the external tubular portion. Due to the well-developed endoplasmic reticulum in the cells of this region of the gland, a pronounced synthesis of proteins would occur. After leaving the cell and crossing the lumen of the external tubules, these components would arrive to the convoluted gland area, inside the reservoir. There, they could be modified by the secretion of these glands (mainly the cells facing the reservoir lumen), which could add other molecules to produce a final blend.

\section{ACKNOWLEDGEMENTS}

We thank FAPESP for financial support. We are also grateful to Cristiane M. Mileo for assistance with the preparation of the schematic figures.

\section{REFERENCES}

1 ABREU RM. Padrões citoquímicos das glândulas de veneno de operárias de Apis mellifera L. (Hymenoptera, Apidae). Rio Claro: Universidade Estadual Paulista, Instituto de Biociências, 2000. 176p. [Tese-Doutorado].

2 ALVES JÚNIOR VV. Estudo da herança do caráter comprimento da glândula ácida em operárias de abelhas africanizadas (Apis mellifera) (Hymenoptera, Apidae). Rio Claro: Universidade Estadual Paulista, Instituto de Biociências, 1992. 112p. [Tese - Doutorado].

3 BORDAS ML. Apareil glandulaire des Hymenoptéres. Ann. Sci. Nat. Zool., 1895, 19, $1-362$.

4 BRIDGES AR. Fine structure of the honey bee (Apis mellifera L.) venom gland and reservoir - A system for the secretion and storage of a naturally produced toxin. Microsc. Soc. (Canada), 1977, 4, 50.

5 BRIDGES AR., OWEN MD. The morphology of the honeybee (Apis mellifera L.) venom gland and reservoir. J. Morphol., 1984, 181, 69-86.

6 CAETANO FH., JAFFÉ K., ZARA FJ. Formigas: biologia e anatomia. Araras: Topázio, 2002. 131p.

7 CARLET G. Sur le venin des hymenoptéres et ses organes secreteus. C. R. Acad. Sci., 1884, 98, 1550-1. 
F. B. Britto et al. ULTRAMORPHOLOGICAL ANALYSIS OF THE VENOM GLANDS AND THEIR HISTOCHEMICAL RELATIONSHIP WITH THE CONVOLUTED GLANDS IN THE PRIMITIVE SOCIAL PAPER WASP Polistes versicolor (HYMENOPTERA: VESPIDAE). J. Venom. Anim. Toxins incl. Trop. Dis., 2005, 11, 2, p. 173

8 CRUZ-LANDIM C., KITAJIMA EW. Ultraestrutura do aparelho venenífero de Apis (Hymenoptera, Apidae). Mem. Inst. Butantan, 1966, 33, 701-10.

9 HERMANN HR. Elaboration and reduction of the venom apparatus in aculeate Hymenoptera. In: Defensive mechanisms in social insects. New York:

Fraeger, 1984: 259.

10 JUNQUEIRA LCU., JUNQUEIRA LMM. Técnicas básicas de citologia e histologia. São Paulo: Livraria Santos, 1983: 123.

11 KANWAR U., BRAR N. Morphological and cytological studies in the venom gland of the honeybee, Apis dorsata. Res. Bull. Panjab Univ. Sci., 1982, 23, 37-41.

12 KANWAR KC., KANWAR U. Fine structure of the venom gland of Vespa orientalis. Toxicon, 1975, 13, 102-3.

13 KARLSON P., LUSHER M. Pheromones: a new term for a class of biologically active substances. Nature, 1959, 183, 55-6.

14 KERR WE., LELLO E. Sting glands in stingless bees a vestigial character (Hymenoptera, Apidae). J. N. Y. Entomol.. Soc., 1962, 70, 190-214.

15 LELLO E. Glândulas anexas do aparelho de ferrão das abelhas (Hymenoptera, Apoidea). Rio Claro: Universidade Estadual Paulista, Faculdade de Filosofia Ciências e Letras, 1968. 76p. [Tese-Doutorado].

16 MASCHWITZ UWJ., KLOFT W. Morphology and function of the venom apparatus of insects - bees, wasps, ants and caterpillars. In: BÜCHERL W., BUCKLEY E. Eds. Venomous animals and their venoms. New York: Academic Press, 1971: 1-60

17 MELLO MLS., VIDAL BC. Práticas de biologia celular. São Paulo: Edgard Blücher, 1980. 69p.

18 NASCIMENTO FS., CRUZ-LANDIM C. Correlação da hierarquia social de dominância com o desenvolvimento das glândulas associadas ao aparelho de ferrão de Polistes versicolor (Olivier, 1791) (Hymenoptera, Vespidae). Rev. Bras. Biol., 1997, 57, 709-18.

19 NOIROT N., QUENNEDEY A. Fine structure of insect epidermal glands. Annu. Rev. Entomol., 1974, 19, 61-80. 
F. B. Britto et al. ULTRAMORPHOLOGICAL ANALYSIS OF THE VENOM GLANDS AND THEIR HISTOCHEMICAL RELATIONSHIP WITH THE CONVOLUTED GLANDS IN THE PRIMITIVE SOCIAL PAPER WASP Polistes versicolor (HYMENOPTERA: VESPIDAE). J. Venom. Anim. Toxins incl. Trop. Dis., 2005, 11, 2, p. 174

20 ORTIZ G., CAMARGO-MATHIAS MI. Morphohistological study of the venom gland in workers of the ant Pachycondyla striata F. Smith (Hymenoptera: Ponerinae). Sociobiology, 2003, 42, 103-16.

21 PALADE G. Intracellular aspects of the process of protein synthesis. Science, 1975, 189, 347-58.

22 RATCLIFFE NA., KING PE. Morphological, ultrastructural, histochemical and eletrophoretic studies on the venom system of Nasonia vitripennis walker (Hymenoptera, Pteromalidae). J. Morphol., 1970, 127, 177-204.

23 SCHOETERS E., BILLEN J. Morphology and ultrastructure of a secretory region enclosed by the venom reservoir in social wasp (Insecta, Hymenoptera). Zoomorphology, 1995, 115, 63-71.

24 SCHOETERS E., BILLEN J. Morphology and ultrastructure of the convoluted gland in the ant Dinoponera australis (Hymenoptera, Formicidae). Int. J. Insect Morphol. Embryol., 1995, 24, 323-32.

25 SILVEIRA OT., CAETANO FH. A morphometric study of sting glands in vespid wasps (Hymenoptera, Vespidae). Sociobiology, 1993, 23, 45-62.

26 SILVEIRA OT., CAETANO FH. Comparative anatomy of sting glands in neotropical vespid wasps (Vespidae, Polistinae, Eumeninae). Naturalia, 1993, 18, 95-108. 